Gut, 1976, 17, 435-438

\title{
Effect of intraduodenal magnesium sulphate on pancreas and gallbladder of man
}

\author{
J. H. B. SAUNDERS, B. THJODLEIFSSON, AND K. G. WORMSLEY1 \\ From the Department of Therapeutics, University of Dundee, Dundee
}

SUMMARY Magnesium sulphate has previously been used as a purgative in a test involving the measurement of the faecal excretion of pancreatic enzymes. In order to validate the use of magnesium sulphate for this purpose, in 18 individuals the pancreatic and biliary response to intravenous infusion of secretin $(1 \mathrm{CU} / \mathrm{kg}-\mathrm{h})$ plus CCK $(1 \mathrm{IU} / \mathrm{kg}-\mathrm{h})$ were compared with the responses to one of three dose-rates of magnesium sulphate infused into the duodenum. The effect of magnesium sulphate was also studied during the coincident intravenous administration of the hormones. Intraduodenal magnesium sulphate did not stimulate the secretion of bicarbonate into the duodenum but did evoke the secretion of pancreatic enzymes and discharge of bile. The pancreatic response to the exogenous hormones was not altered by coincident intraduodenal infusion of magnesium sulphate. We conclude that magnesium sulphate is a satisfactory purgative for speeding the intestinal transit of pancreatic enzymes.

In a previous communication (Sale et al., 1974) we described the use of magnesium sulphate as a purgative to speed the intestinal transit and excretion in the faeces of the pancreatic enzymes which had been secreted in response to intravenous secretin and cholecystokinin-pancreozymin (CCK). In the present study, we have examined the effect of magnesium sulphate solutions on the pancreatic response to the hormones in order to determine whether the magnesium sulphate by itself has any effect on pancreatic exocrine secretion or alters the response to the hormones.

\section{Methods}

Eighteen patients, undergoing routine pancreatic secretory investigations, gave informed consent to two (and, in two cases, three) studies. After an overnight fast, each individual was intubated with a multilumen tube which was sited radiologically so that the infusion site was placed proximally in the descending duodenum, with the duodenal aspiration sites $10 \mathrm{~cm}$ distally and the gastric aspiration holes in the antrum.

In random order, on different days, each individual

${ }^{1}$ Address for communications: KGW, Ninewells Hospital, Dundee DD2 1UB, Scotland.

Received for publication 9 February 1976 received either a continuous intravenous infusion of secretin (1 clinical unit/kg-hour) plus CCK (1 Ivy unit $/ \mathrm{kg}-\mathrm{h}$ ) for 45 minutes, or an intraduodenal infusion of magnesium sulphate in a dose of $\mathbf{4 0}$ $\mathrm{mmol} / \mathrm{l}(10 \mathrm{~g} / \mathrm{l})$ (six subjects), $160 \mathrm{mmol} / \mathrm{l}(40 \mathrm{~g} / \mathrm{l})$ (eight subjects), or $640 \mathrm{mmol} / \mathrm{l}(160 \mathrm{~g} / \mathrm{l})$ (six subjects) at a rate of $2.5 \mathrm{ml}$ per minute for 90 minutes, during the last 45 minutes of which the same dose of secretin (1 CU/kg-h) plus CCK (1 IU/kg-h) were also infused intravenously. The hormones were purchased from the GIH Laboratory, Karolinska Institutet, Stockholm, Sweden.

Gastric and duodenal contents were aspirated continuously in 15-minute batches and volumes recorded. The concentration of bicarbonate was measured by adding an excess of acid, boiling, and backtitrating to $\mathrm{pH} 7$ with an automatic titrator; tryptic activity was measured photometrically, using benzoyl-arginine-p-nitroanilide as substrate, and bile pigment was expressed as icteric index (Table).

Outputs refer to the total 45-minute responses to each stimulant schedule.

The significance of difference between groups was assessed by means of the Mann-Whitney $U$ test.

\section{Results}

BICARBONATE OUTPUT

Infusion of magnesium sulphate into the duodenum 


\begin{tabular}{|c|c|c|c|c|c|}
\hline \multirow{2}{*}{$\begin{array}{l}\text { Output } \\
\text { (mmol/45 } \mathrm{min})\end{array}$} & \multirow{2}{*}{$\begin{array}{l}\text { Subjects } \\
\text { (no.) }\end{array}$} & \multirow{2}{*}{$\begin{array}{l}\mathrm{MgSO} \\
\text { concentration } \\
(\text { mmol/l) }\end{array}$} & \multicolumn{3}{|l|}{ Stimulus } \\
\hline & & & $\begin{array}{l}S+C C K \\
\text { only }\end{array}$ & $\begin{array}{l}\mathrm{MgSO} \\
\text { only }\end{array}$ & $\begin{array}{l}S+C C K \\
+ \\
M_{g S O}\end{array}$ \\
\hline Bicarbonate & $\begin{array}{l}6 \\
8 \\
6\end{array}$ & $\begin{array}{r}40 \\
160 \\
640\end{array}$ & $\begin{array}{l}22.6 \pm 5.2 \\
18.0 \pm 7 \cdot 1 \\
13.3 \pm 2.4\end{array}$ & $\begin{array}{l}0.3 \pm 0.3 \\
1.1 \pm 1.1 \\
0.4 \pm 0.5\end{array}$ & $\begin{array}{lr}21.4 \pm & 6.6 \\
19.2 \pm & 10.8 \\
15.7 \pm & 8.8\end{array}$ \\
\hline Trypsin & $\begin{array}{l}6 \\
8 \\
6\end{array}$ & $\begin{array}{r}40 \\
160 \\
640\end{array}$ & $\begin{array}{r}213 \pm 72 \\
184 \\
96 \\
967\end{array}$ & $\begin{array}{l}25 \pm 36 \\
54 \pm 49 \\
53 \pm 56\end{array}$ & $\begin{array}{l}202 \pm 87 \\
183 \pm 110 \\
110 \pm 49\end{array}$ \\
\hline Bile pigment & $\begin{array}{l}6 \\
8 \\
6\end{array}$ & $\begin{array}{r}40 \\
160 \\
640\end{array}$ & $\begin{array}{l}20.6 \pm 7.9 \\
17.4 \pm 8.7 \\
21.6 \pm 9.3\end{array}$ & $\begin{array}{r}4.7 \pm 5.6 \\
9.7 \pm 11.2 \\
19.4 \pm 21.8\end{array}$ & $\begin{array}{l}22.9 \pm 10.9 \\
25 \cdot 3 \pm 14 \cdot 6 \\
27 \cdot 7 \pm 19 \cdot 2\end{array}$ \\
\hline
\end{tabular}

Table

S + CCK: secretin + CCK - PZ.

The values indicate means $\pm \mathrm{SD}$.

did not stimulate the secretion of bicarbonate (Figure).

The mean bicarbonate output in response to the exogenous hormones was not significantly affected by any of the dose-rates of infused magnesium sulphate (Figure).

\section{TRYPSIN OUTPUT}

Magnesium sulphate evoked increasing pancreatic secretion of enzymes as the dose-rate of infusion into the duodenum increased, so that the response (expressed as proportion of the response to the exogenous hormones) to the infusion of $160 \mathrm{mmol} / \mathrm{l}$ magnesium sulphate was significantly greater $(P<$ 0.02) than the response to $40 \mathrm{mmol} / 1$ (Figure). Similarly, the output of trypsin during infusion of $640 \mathrm{mmol} / \mathrm{l}$ was greater than the response to the medium dose of magnesium sulphate $(160 \mathrm{mmol} / \mathrm{l})$, but the difference did not reach a level of statistical significance $(P>0.05)$.

The duodenal infusion of magnesium sulphate did not significantly affect the mean secretion of trypsin in response to the exogenous hormones (Figure).

\section{BILE PIGMENT OUTPUT}

In response to the duodenal infusion of magnesium sulphate, the secretion of bile pigment into the duodenum increased, both in absolute terms and compared with the response to exogenous hormones. The increase was significant on increasing the doserate of magnesium sulphate from 40 to $160 \mathrm{mmol} / \mathrm{l}$ $(\mathrm{P}<0.05)$ (Figure).

All three dose-rates of magnesium sulphate increased the cholecystokinetic response to the exogenous hormones, although the increase reached statistical significance only with the dose of 160 $\mathrm{mmol} / \mathrm{l}(\mathrm{P}<0.05)$ (Figure).

\section{Discussion}

Magnesium sulphate has long been known to affect the secretory and motor functions of the alimentary tract (Soper, 1925). Among its actions, magnesium sulphate in the small intestine has been reported to exert a weak secretagogue effect on pancreatic exocrine function (Simon, 1927; Hirschberg, 1928; McClure et al., 1934, McClure, 1936), stimulating principally the secretion of enzymes. The present study has shown that magnesium sulphate exerts an increasingly potent stimulant effect on the secretion of pancreatic enzymes as the dose-rate of magnesium sulphate infused into the duodenum increases. Even high concentrations of magnesium sulphate did not inhibit the pancreatic secretory response to exogenous hormones, unlike the inhibition elicted by other hypertonic solutions in the upper small intestine (Lawrence et al., 1961; Dyck, 1971).

The very potent effect of intraduodenal magnesium sulphate in causing discharge of bile into the duodenum (Lyon, 1919; Matsuo, 1924; Simon, 1927; Boyden, 1928; Boyden and Birch, 1930; Ivy, et al., 1933; Bergh and Layne, 1942; Necheles and Kozoll, 1942; Boyden et al., 1943) has been confirmed by the present study, which has shown that infusion of magnesium sulphate into the duodenum elicits contraction of the gallbladder which is as great as that evoked by the combination of exogenous hormones in the dosage used in the present study. When administsred together with the exogenous hormones, the duodenal infusion of magnesium sulphate augmented the contraction of the gallbladder, compared with the response to the exogenous hormones alone.

The mechanism of action of intraduodenal magnesium sulphate on pancreas and gallbladder is not 

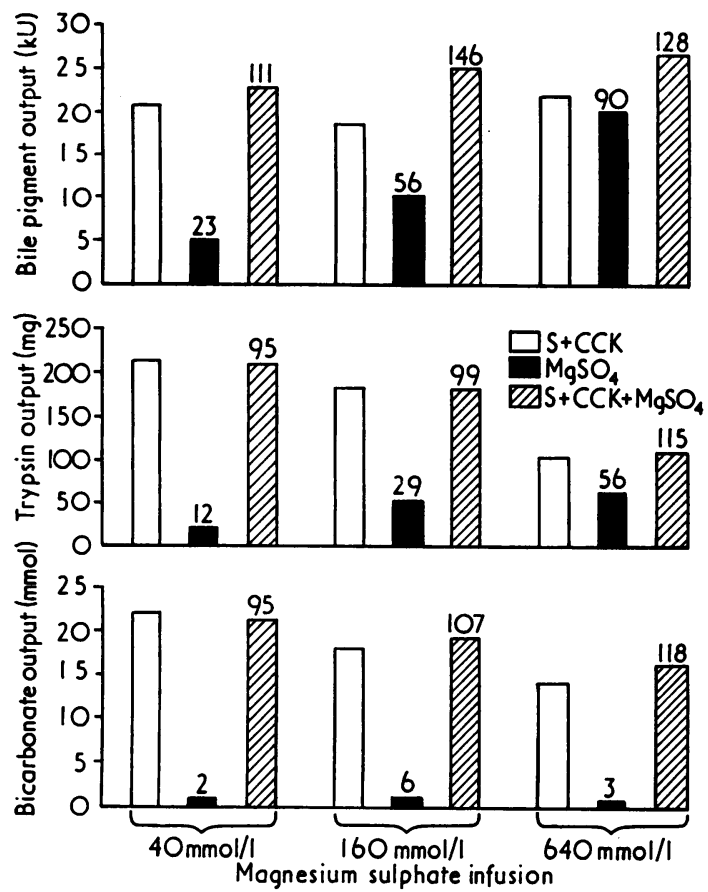

Figure Bicarbonate, trypsin, and bile pigment secretion in response to exogenous hormones and magnesium sulphate. Each vertical bar represents the mean value of the response to intravenous secretin plus CCK alone (open columns); intraduodenal magnesium sulphate alone (solid columns); and the combination of the intravenous hormones together with intraduodenal magnesium sulphate (hatched columns). The numbers just above the columns, representing the responses to magnesium sulphate alone and together with exogenous hormones, denote the mean percentage value of the appropriate response relative to the response to secretin plus $C C K$ alone in the same individuals. The dose-rates of magnesium sulphate are depicted at the bottom of each triad of columns.

known. It seems unlikely that the stimulant effect of magnesium sulphate on the pancreas is an indirect one, secondary to the bile salts discharged into the duodenum as a result of magnesium sulphateinduced cholecystokinesis, since high concentrations of bile salts in the duodenum inhibit the bicarbonatesecretory response to exogenous secretin (Wormsley, 1970), while hormonally-stimulated bicarbonate secretion was not affected by magnesium sulphate. Magnesium sulphate has been thought to release CCK from the small intestine both on the basis of haemoperfusion studies (Crema et al., 1966) and because preliminary results indicate an increase of circulating immunoreactive CCK-like material (Harvey et al., 1973; Grayburn et al., 1975). However, although the overall pattern of response to the duodenal infusion of magnesium sulphate resembles the response to intravenous infusion of the partially purified small intestinal extract marketed as 'CCK', there are some differences which preclude accepting, at present, that magnesium sulphate acts only by releasing CCK. Thus, increasing doses of CCK given parenterally in man elicited progressive increase (albeit small) in the output of bicarbonate (Wormsley, 1969) while magnesium sulphate had no such effect. The human exocrine pancreas is more sensitive - that is, has a lower threshold to stimulation-to parenteral CCK than the gallbladder (Malagelada et al., 1973), while the present study has shown that the cholecystokinetic response to intraduodenal magensium sulphate is relatively greater than trypsin secretion in response to all doses of magnesium sulphate, at least when compared with the response to the combination of exogenous hormones used in the present study. Moreover, the addition of the stimulus provided by exogenous hormones results in further, undiminished discharge of bile from the gallbladder previously only partially emptied by the stimulus of intraduodenal magnesium sulphate (Boyden et al., 1943), while the stimulus to cholecystokinesis provided by increase in the dose of CCK only slightly augments the bile discharge evoked by CCK (Wormsley, 1969), perhaps because large doses of intravenously administered CCK cause contraction of the cholecystocystic sphincter (Torsoli, 1970).

We conclude that the stimulant effect of magnesium sulphate on the pancreatic secretion of enzymes, together with absence of any interference with the pancreatic response to exogenous stimulant hormones, makes magnesium sulphate a satisfactory purgative for use in speeding the intestinal transit of pancreatic enzymes.

K.G.W. gratefully acknowledges a research grant from the Wellcome Foundation. Mrs F. Dear and Miss S. Drummond provided expert technical assistance.

\section{References}

Bergh, G. S., and Layne, J. A. (1942). The effect of magnesium sulphate upon the sphincter of Oddi of man. American Journal of Digestive Diseases. 9, 162-165.

Boyden, E. A. (1928). An analysis of the reaction of the human gallbladder to food. Anatomical Record, 40, 147189.

Boyden, E. A., Bergh, G. S., and Layne, J. A. (1943). An analysis of the reaction of the human gallbladder and sphincter of Oddi to magnesium sulfate. Surgery, 13, 723733.

Boyden, E. A.. and Birch, C. L. (1930). Reaction of gallblad- 
der to stimulation of gastrointestinal tract. I. Response to substances injected into the duodenum. American Journal of Physiology, 92, 287-300.

Crema, A., Benzi, G., Frigo, G. M., and Berté, F. (1966). On the mechanism of action of magnesium sulphate upon the gallbladder. Gastroenterologia, 105, 109-114.

Dyck, W. P. (1971). Influence of intrajejunal glucose on pancreatic exocrine function in man. Gastroenterology, 60, 864-869.

Grayburn, J. A., Harvey, R. F., Jennings, R. D., Dowsett, L., and Hartog, M. (1975). Relationship between changes of serum cholecystokinin-pancreozymin and serum insulin after different stimuli. Diabetologia, 11, 35-38.

Harvey, R. F., Dowsett, L., Hartog, M., and Read, A. E. (1973). A radioimmunoassay for cholecystokinin-pancreozymin. Lancet, 2, 826-828.

Hirschberg, L. (1928). Sekretorische Funktion der Leber, des Pankreas und des Magens nach Einführung von $\mathbf{M g S O}_{4}$ ins Duodenum. Archiv für Verdauungskrankheiten, 44, 393405.

Ivy, A. C., Voegtlin, W. L., and Greengard, H. (1933). The physiology of the common bile duct. A singular observation. Journal of the American Medical Association, 100, 1319-1320.

Lawrence, W., Khentigan, A., Hudock, J., and Vanamee, P. (1961). The effect of intraduodenal administration of hypertonic glucose solution on external pancreatic function. Surgery, 49, 666-675.

Lyon, B. B. V. (1919). Diagnosis and treatment of diseases of the gallbladder and biliary ducts. Journal of the American Medical Association, 73, 980-982.

McClure, C. W. (1936). Observations on the physiology and pathologic physiology of external pancreatic functions. Review of Gastroenterology, 3, 1-26.
McClure, C. W., Huntsinger, M. E., and Fernald, A. T. (1934). Effects of administration of pure foodstuffs and inorganic substances on external secretory activities of the liver, pancreas and stomach.American Journal of Physiology, 107, 94-112.

Malagelada, J. R., Go, V. L. W., and Summerskill, W. H. J. (1973). Differing sensitivities of gallbladder and pancreas to cholecystokinin-pancreozymin (CCK-PZ) in man. Gastroenterology, 64, 950-954.

Matsuo, I. (1924). Magnesium sulphate as a cause of the evacuation of the gallbladder. Journal of the American Medical Association, 83, 1289-1292.

Necheles, H., and Kozoll, D. D. (1942). A study of the sphincter of Oddi in the human and in the dog. American Journal of Digestive Diseases, 9, 36-40.

Sale, J. K., Goldberg, D. M., Thjodleifsson, B., and Wormsley, K. G. (1974). Trypsin and chymotrypsin in duodenal aspirate and faeces in response to secretin and cholecystokinin-pancreozymin. Gut, 15, 132-138.

Simon, H. (1927). Die Ergebnisse und Methoden der Pankreasfunktions Prüfung. Ergebnisse der Inneren Medizin und Kinderheilkunde, 32, 83-118.

Soper, H. W. (1925). The story of magnesium sulphate with special reference to its use in biliary drainage. American Journal of Medical Science, 169, 398-407.

Torsoli, A., Ramorino, M. L., and Alessandrini, A. (1970). Motility of the biliary tract. Rendiconti Gastroenterologia, 2, 67-80.

Wormsley, K. G. (1969). A comparison of the response to secretin, pancreozymin and a combination of these hormones, in man. Scandinavian Journal of Gastroenterology, 4, 413-417.

Wormsley, K. G. (1970). Stimulation of pancreatic secretion by intraduodenal infusion of bile-salts. Lancet, 2, 586-588. 